This item was submitted to Loughborough's Research Repository by the author.

Items in Figshare are protected by copyright, with all rights reserved, unless otherwise indicated.

\title{
Institutional voids and organization studies: Towards an epistemological rupture
}

PLEASE CITE THE PUBLISHED VERSION

https://doi.org/10.1177/0170840618819037

\section{PUBLISHER}

(c) The Authors. Published by SAGE Publications

\section{VERSION}

AM (Accepted Manuscript)

\section{PUBLISHER STATEMENT}

This work is made available according to the conditions of the Creative Commons Attribution-NonCommercialNoDerivatives 4.0 International (CC BY-NC-ND 4.0) licence. Full details of this licence are available at: https://creativecommons.org/licenses/by-nc-nd/4.0/

\section{LICENCE}

CC BY-NC-ND 4.0

\section{REPOSITORY RECORD}

Bothello, Joel, Robert S. Nason, and Gerhard Schnyder. 2019. "Institutional Voids and Organization Studies: Towards an Epistemological Rupture”. Loughborough University. https://hdl.handle.net/2134/36638. 


\title{
Institutional voids and organization studies: Towards an epistemological rupture
}

\begin{abstract}
In this essay, we critique the usage of the term 'institutional void' to characterize nonWestern contexts in organizational studies. We explore how 'conceptual stretching' of institutional voids - specifically, the theoretical and geographic expansion of the concept has led not only to poor construct clarity, but also pejorative labeling of non-Western countries. We argue that research using this term perpetuates an ethnocentric bias by deifying market development and overlooking the richness and power of informal and non-market institutions in shaping local economic activity. We call for an 'epistemological rupture' to decolonize organizational scholarship in non-Western settings and facilitate contextually grounded research approaches that allow for more indigenous theorization.
\end{abstract}

\section{Keywords}

Institutional voids, conceptual stretching, epistemological rupture

\section{Acknowledgments}

The authors contributed equally and are listed alphabetically. We would first like to thank our editor Trish Reay for her support, as well as the three anonymous reviewers who helped shape this article. We would also like to thank Michael Carney for his detailed feedback on an early draft, in addition to Anna Kim, Tima Bansal, Ann Langley, Russ Fralich, Alex 
Bitektine and other participants of the Montreal Organizational Writing Workshop (MOWW) for their advice and guidance. 
'Disorder is simply the order we are not looking for.'

H. Bergson (1969[1934]: 61, our translation)

\section{Institutional voids and organization studies: Towards an epistemological rupture}

In early 2018, U.S. President Donald Trump reportedly referred to African nations as well as Haiti and El Salvador as 'shithole countries.' While many decried his comments as unacceptable and racist, they were symptomatic of a more pervasive ethnocentric mindset, one that permeates even academia (e.g. Gilley, 2018). We argue that organizational scholarship is no exception, and is rife with implicit accounts of the superiority of the West vis-à-vis non-Western contexts. In this essay, we focus on the term 'institutional voids,' arguing that it has evolved into an academic euphemism for 'shithole countries'.

Institutional void is a term often used by scholars seeking to characterize non-Western economies (Khanna \& Palepu, 1997, 2000b, 2010). Offering a contrast to Western markets, institutional voids are defined as contexts lacking 'market-supporting and contractenforcement institutions to efficiently facilitate exchange between firms' (Pinkham \& Peng, 2017, p. 1). For instance, strong legal institutions are seen as enabling both the enforcement of contracts and the development of equity markets necessary for financing firm growth (La Porta, Lopez de Silanes, Shleifer, \& Vishny, 1998). In the past two decades, the institutional 
void concept has found traction in many academic domains as it offers a means to capture differences in non-Western contexts in a manner facilitating comparability with Western and particularly Anglo-Saxon - economies. The term is invoked, to various degrees, to account for the existence of conglomerates and business groups, family firms, social enterprises, and even NGOs (Anheier, 2014; Carney, Gedajlovic, Heugens, Van Essen, \& Van Oosterhout, 2011; Gedajlovic, Carney, Chrisman, \& Kellermanns, 2012; Mair, Marti, \& Ventresca, 2012).

Yet we argue that this concept is replete with vocabulary that privileges Western institutions (Banerjee, 2003; Dar, 2017). The idea of institutional voids is built on a narrow transaction cost conceptualization of institutions as regulatory 'rules of the game', ignoring a more holistic treatment of institutions as 'regulative, normative and cultural-cognitive elements that, together with associated activities and resources, provides stability and meaning to social life' (Scott, 2014, p. 56). Further, we document a process of conceptual stretching (Sartori, 1970) in the literature using the term institutional void(s). We suggest that as Western social scientists have become increasingly interested in explaining non-Western contexts, they have resorted to 'vague [and] amorphous conceptualizations' (Sartori, 1970, p.1034) to increase the theoretical and geographical applicability of institutional voids. As a result, we argue that the burgeoning literature on institutional voids is driven by rote 
application of the concept by researchers who are too often separated from the contexts about which they theorize. We contend that the concept's increasing 'extension', i.e. 'class of things to which a word applies' (Sartori, 1970, p. 1051) has compromised its 'intension' or the collection of properties determining the things to which the word applies.

The result, we argue, is an increasingly tenuous theoretical foundation and an unfounded benchmarking of foreign countries' institutional systems against an idealized Western, and often Anglo-American model (Ozkazanc-Pan, 2008). What began as an attempt to move away from universalistic approaches to explore and theorize foreign institutional contexts has evolved, intentionally or not, into a pejorative and counterproductive portrayal of non-Western economies as institutionally inferior. Despite recent attempts to recast the concept in a less enthnocentric fashion (e.g. Mair et al., 2012), these efforts do not resolve the inherent teleological assumptions that non-Western countries 'evolve' towards more Western-style institutions - albeit with some local flavour. We suggest that the result is voluminous but inconsistent and biased knowledge accumulation, on institutional voids specifically and non-Western economies generally.

Some organizational scholars propose that the conceptual creep of a term can be countered by a narrower and stricter adherance to construct boundaries (Hirsch \& Levin, 1999, p. 200). This is certainly part of the issue, although our criticism is targeted at the 
normative implications stemming from the initial premises and overly reductionist application of the concept, which cannot be addressed by better definitions.

Accordingly, we propose abandoning the label institutional voids altogether. Importantly, we are not implying that scholars using the term are bigoted or even that the term has not proven useful for advancing research. The initial intention in developing the term appears laudable, and we ourselves are cognizant that our own ethnocentric biases may color our interpretation of unfamiliar contexts. Nonetheless, we call for an 'epistemological rupture' (Bachelard, 1938) to decolonize current approaches to non-Western settings. As our opening quote from Bergson indicates, we suggest that the literature on institutional voids characterizes settings by disorder primarily because it fails to recognize pre-existing, alternative order(s). We call for an earnest pursuit of understanding these alternative arrangements to enable greater authenticity in theoretical development regarding nonWestern economies.

\section{Origins of institutional voids}

The institutional voids concept emerged in management and organization studies in the 1990s as scholars sought to reconcile theoretical developments in finance and institutional economics with patterns of corporate governance in non-Western countries (North, 1990). The notion was born of an obvious but important observation for the purposes of theoretical 
development: non-western organizations are often highly distinct from their Western counterparts, with some measure of this variation attributed to local institutional arrangements (Leff, 1978).

Khanna and Palepu (1997) offered one of the most compelling contributions to this discussion, providing comparative accounts of business conduct and structure in foreign countries based on differences in 'rules of the game' - i.e. economic institutions - of exchange (North, 1990). In these accounts, many firm-level characteristics could be readily explained as organizational responses to the costs of transacting in the market, which in turn were based on the presence or absence of market-supporting institutions (Chang \& Hong, 2000; Chittoor, Kale, \& Puranam, 2015). Large Asian conglomerates, for example, were inclined towards brand leverage, heavy vertical integration, interlocking directorates and intra-group trading arrangements to compensate for 'information [asymmetry] problems, imperfect contract enforcement, inability to enforce property rights and flawed regulatory structure' (Khanna \& Palepu, 2000a, p. 888). Settings that lacked the requisite marketsupporting institutions were labelled as institutional voids.

This early work of Khanna and Palepu leveraged explanations from New Institutional Economics to account for firm evolution in a multitude of non-Anglo-Saxon contexts. In contrast to sociological accounts, where institutions can be cultural-cognitive, normative and 
regulative (Scott, 2014), Khanna and Palepu conceptualized institutions as purely regulative, market-enabling 'rules of the game' (cf. Mair et al., 2012, p. 821). Building upon arguments from Leff (1978), the authors specified an absence of specific regulatory institutions or market intermediaries (e.g. information intermediaries, regulation and contract enforcement) that resulted in inefficient capital, labor and product markets (Khanna \& Palepu, 1997).

\section{Diffusion and conceptual stretching}

The concept of instutional voids coined by Khanna and Palepu (1997) proved to be analytically tractable, producing a spate of studies. Figure 1 below presents the number of articles with institutional void(s) in the abstract of all results in the EBSCOhost Business Source Complete database. This data does not represent an exhaustive use of the concept, but does indicate its use within management and organization studies. We observe that use of the term has grown from a handful of articles a year in the late-1990s to 38 articles in the year 2017 alone. 'Institutional void' has become institutionalized - with rapid growth in literature driven by an extension into scholarly domains, contexts, and phenomena quite removed from its origins. We suggest that this extension of applicability accompanies a process of conceptual stretching that has created a host of problems which we outline below.

[Insert Figure 1 about here] 


\section{Problem 1: Narrow Scope, Broad Application}

Using the same corpus of articles from EBSCO, we also provide a map illustrating which countries/regions have been characterized by institutional voids. There is a clear extension of the term to cover an increasingly broad and diverse set of countries from Afghanistan (Hanekom \& Luiz, 2017) to Zimbabwe (Davies \& Torrents, 2017), with a particularly outsized emphasis on China. The term is even used to classify entire continents such as Africa (e.g. Getachew \& Beamish, 2017) and Latin America (e.g. Castellacci, 2015). Oddly, developed countries like Taiwan (Luo \& Chung, 2013) and Germany (e.g. Beveridge, 2012) have also been labelled as institutional voids.

[Insert Figure 2 about here]

Clearly the concept of institutional void has been applied with broad strokes. Further, we suggest that the focus on formal legal systems and judiciary enforcement of rules reflects an ethnocentric bias in the institutional void concept and a particular fetishization of the United States. In early work, Khanna and Palepu applied an important disclaimer that their work was not intended to foster the idea that 'one institutional context [is] superior to others' (Khanna \& Palepu, 1997). The conclusions of the institutional void literature, though, imply otherwise: given the premise that institutional voids are hindrances and that the US is an 'extreme example of a country where there are relatively few voids' (Khanna \& Palepu, 
1997), the logical conclusion is that the US is a near-ideal institutional environment. Indeed, this is reinforced when institutional void is later defined more broadly as the ' $[\ldots]$ absence in emerging markets of things we take for granted in our backyard in Boston' (Khanna \& Palepu, 2010).

Although the original formulation of the institutional void concept was narrow and US-centric, the increasing extension of the term results in nebulous conceptualization and inconsistent application. This creates a situation where it is not very clear what an institutional void is, but it is clear what an institutional void is not (i.e. a void is not the US). We suggest that this trajectory has undermined the theoretical fidelity of the concept, reinforcing problematic assumptions and fostering conceptual inaccuracy.

In more recent literature, the utilization of the institutional void label often veers away from the underlying legal and political frameworks and economic 'rules of the game,' and instead is conflated with anything that increases costs of transactioning. As an example, Khanna and Palepu (2010) recount an anecdote of Tetra-Pak overcoming the 'specific institutional void' of missing cold-chain distribution in Argentina. Their account identifies logistical failures in a particular industry as a contextual problem. Yet, it is not one that can be precisely attributed to any missing market-enabling institutions. This type of conflation is a recurring theme in this literature: deficiencies in telecommunications, transportation, or 
physical infrastructure, for example, are observed as characteristics of non-Western countries and impediments to market-based transactions (Hoskisson, Johnson, Tihanyi, \& White, 2005). They are therefore considered as institutional voids or 'rigidities' (Fisman \& Khanna, 2004; Santangelo \& Meyer, 2011), even if the link to the legal and political institutional environment is dubious.

In other situations, the presence rather than absence of a Western legal institution is considered to constitute an institutional void. Santangelo and Meyer (2011), for instance, consider that trade unions, a dominant feature in many continental European economies (Hall \& Soskice, 2001) contribute to institutional voids: '[c]omplex decisions processes, such as negotiations with trade unions, create rigidities that slow down adjustment processes and raise barriers to exit' (Santangelo \& Meyer 2011: 898). Regulation in some areas is similarly viewed as an institutional void and hence undesirable; in the labour market, for instance, it potentially 'greatly reduce[s] firms' ability to lay off staff, or even to reassign employees to new roles' (Santangelo \& Meyer 2011: 899). As such, treating labour regulation as contributing to an institutional void is based on the (contested) assertion that labour markets function better with lower levels of regulation (cf. Deakin \& Sarkar, 2008). This illustrates how the inherent ethnocentricity of the concept turns the literal meaning of institutional void (i.e. absence) on its head. 
The critiques we outline here demonstrate that the institutional void concept has been stretched into divergent conceptualizations of institutions. The concept simultaneously promotes a rigid and tractable set of principles, yet is undefined enough regarding basic terminology to allow for increased extension into new theoretical and phenomenological domains. The rampant 'cherry-picking' similarly extends to empirical and methodological issues, as we outline in the subsequent section.

\section{Problem 2: Empirical convenience and methodological shortcomings}

Institutional voids are notoriously difficult to operationalize (Khanna \& Rivkin, 2001) with many empirical decisions driven either by convenience or rough approximations. Researchers have generally avoided measuring institutional voids by limiting their investigations to contexts which have been previously (and in our view often arbitrarily) labelled as institutional voids (e.g. Chittoor et al., 2015; Fisman \& Khanna, 2004; Manikandan \& Ramachandran, 2015), or they rely upon generic indices that evaluate the institutional 'voidness' of countries based on criteria such as 'credit/equity market efficiency' or 'business freedom' (Ghoul, Guedhami, \& Kim, 2017). However, comparing these two approaches reveals a lack of consensus regarding what the defining properties (or intension) of an institutional void are. For instance, Taiwan, a country characterized as riddled with 
institutional voids by Luo and Chung (2013) until 2005, ranked $11^{\text {th }}$ that year in the IMD World Competition Scoreboard, ahead of 'developed' countries like New Zealand, Ireland and the U.K. (IMD, 2005), none of which are labelled as institutional voids in Figure 2.

In the handful of cases where authors more directly measure institutional voids (e.g. Santangelo \& Meyer, 2011), survey items closely resemble economic freedom indices: e.g. 'experiencing substantive costs or delays' due to procedures for registering a business, obtaining licenses, access to utilities, custom procedures or tax assessment and payments. Aside from the fact that many such survey items do not actually measure the absence of institutionalized rules, but rather their presence (e.g. specific custom procedures), these indices only have an indirect and tenuous empirical link to market development.

In further instances, studies using the institutional voids concept suffer from the flawed assumption that economic and institutional development within nations is homogenous. Entire countries or regions are often characterized as an institutional void, while in reality, there are stark differences across regions: In India, for example, a 2017 corruption survey indicated that $77 \%$ of respondents in the state of Karnataka had experienced corruption in public services, compared with only $3 \%$ in the state of Himachal Pradesh (CMS, 2017). Similarly, in the 2010 Brazil census the illiteracy rate for the state of Sao Paolo was roughly equivalent to that of the US (2\%), while in the impoverished state of 
Alagoas, illiteracy was on par with Haiti (46\%). If market-relevant outcomes are at least partially attributed to regulatory, legal and cultural traditions, we must recognize the heterogeneity in institutional arrangements across provinces and states. Using the term institutional void to indiscriminately characterize an entire nation reflects a preference for analytical simplicity over empiric complexity. The US is no exception: In 2010, ravaged by industrial decline, Detroit had a $27 \%$ unemployment rate, more than three times that of Boston. We sense that 'the lack of things we take for granted in our backyard in Detroit' would be less compelling a formulation of institutional voids.

Admittedly, many institutional concepts suffer from this 'myth of evenly-spread institutions' (cf. Allen, 2004). With institutional voids though, the myth is selectively mobilized to support the premises of the argument. Prosperous, market-oriented enclaves in Western economies are presented as confirmation of a well-functioning national institutional arrangement. Conversely, in non-Western countries, dysfunctional regions and industries are portrayed as evidence of an institutional void that applies across the entire country. This approach artificially inflates the distinction between Western and non-Western countries.

\section{Problem 3: From ontological assumptions to conceptual imperialism}

Much of our critique is targeted at the transaction cost-based premises that undergird institutional voids, namely that 1) humans are opportunistic and self-interested by nature 
(irrespective of context) and 2) markets naturally emerge if opportunism can be minimized and self-interest channeled productively (Williamson, 1981). Since this idealized homo economicus engages in rational cost-benefit analysis, the optimal institutional arrangement imposes visible sanctions against opportunism, thereby reducing transaction costs. Ostensibly, anything short of a formalized rules-based system is deemed to constitute a void.

Yet, as the term institutional void becomes subject to conceptual stretching, we note a problem with terminology: the mobilization of the term 'void' implies that something is not, but should be present. A peer in one of our doctoral seminars, tasked with discussing an institutional void article, stated flatly, 'this article offended me' because her home country was labelled as a setting rife with institutional voids. As such, it is a concept that veils strong normative assumptions under a cloak of objectivity. We detail more specific ontological assumptions revealed through usage of the term:

i) Market Primacy. Within the set of Western values that dominate management and organization studies, the market, and its set of supporting institutions, take priority. For example, Khanna and Palepu (2010: 35) state that 'aggressive state mandates can sometimes be more effective than the democratic process in implementing institutional change [enabling market activity]'. Conversely, where state law is nebulously deemed 'overly enforced and over-tight' in terms of constraining market participants' freedom, informal institutions that 
help actors 'getting around the formal rules' - i.e. circumventing the law - are considered desirable (Estrin \& Prevezer, 2011). This illustrates an apparent internal contradiction in institutional voids, namely that it underscores the importance of a legal order and the rule of law for a functioning market economy, but promotes undermining the very same rule of law and democracy when these are used to restrain markets. To quote the economist Murrary Rothbard, 'what is so terrible about transaction costs? On what basis are they considered the ultimate evil, so that their minimization must override all other considerations of choice, freedom, and justice?' (Rothbard, 1981, p. 547).

ii) Irrelevance of informal institutions. Scholars using the term institutional void largely reserve the term 'institution' for formalized, market supporting institutions, citing property rights, financial access, rule-of-law and courts as the most common examples (Khanna \& Palepu, 2010). In setting the US as a baseline, scholars also tend to bias their analyses to favor Western market-enabling institutions. Consultancies, for instance, are treated as necessary information intermediaries that facilitate efficient market activity (Khanna \& Palepu, 1997) which in turn, favors other complementary, American-dominated institutions such as the business school (Kipping \& Engwall, 2002).

While these conceptual choices are appealing for analytical reasons, they are problematic insofar as they unduly reduce the range of legitimate institutional arrangements 
to a narrow subset of Western-style institutions in the liberal tradition. Informal and cultural institutions are given only token recognition or derided as 'barriers' to good governance practices (e.g. Cumming, Filatotchev, Knill, Reeb, \& Senbet, 2017). As a result, the term institutional void occludes from analysis other obvious and rich institutions (e.g. culture, family, religion) that impact organizations in ways that cannot be captured by transaction cost explanations. For instance, given the embeddedness of family firms - both Western and non-Western - it seems equally (if not more) plausible that such firms would prioritize organization around kinship or political concerns rather than efficiency (Yiu, Lu, Bruton, \& Hoskisson, 2007), with the latter being only a positive externality. Within the dominant narratives surrounding the term, such non-market arrangements only merit consideration insofar as they have an impact on cost (e.g. through compensatory behaviours such as trust).

Furthermore, the narrow focus on transactioning impedes investigation into the tradeoffs involved in market development. Formal markets themselves may create institutional voids in social and cultural relations (Banerjee \& Jackson, 2016; Mishra, 2017). For example, anthropologists demonstrate how the introduction of arm's-length transactions has historically eliminated pre-existing social and trust-based arrangements in local communities (Graeber, 2014). Similarly, formal institutions may be avoided intentionally: in Confucian tradition, the need for laws is often interpreted as a failure of that society's moral standards 
(Lau \& Young, 2013). In this view, laws, not informal institutions are substitutes. By focusing on formalized economic exchange though, the externalities imposed upon informal arrangements by the market become obscured.

iii) Indigenous organizations and practices as 'incomplete'. The assumptions embedded in institutional voids suggest that local organizing principles (e.g. business group affiliation or state involvement) emerge as makeshift responses to flawed institutions. The term 'bricolage', for instance, is often used to characterize the efforts of local entrepreneurs (Baker \& Nelson, 2005; Mair \& Marti, 2009), but this suggests second-best solutions are 'cobbled together' from available resources rather than legitimate practices in their own right. Many indigenous forms and behaviours are historically grounded in the context in which they emerged. Far before the advent of formalized markets, practices such as gift-giving, empathy, and benevolence structured exchange in many societies; many continue to operate in the same way (Graeber, 2014).

The result of the ontological assumptions stemming from the term institutional void is a form of conceptual imperialism. Recent scholarship in top management journals continues to uncritically promote emulation of Western market and corporate governance institutions. Cumming et al. (2017) coin the term 'governance mobility' to promote the export of Western corporate governance rules to fill institutional voids. The authors propose that 
'[p]olicymakers should work to encourage mobility of governance' with support from 'international financial institutions, such as the IMF and World Bank [who] can be transmission sources of governance for developing economies' (Cumming et al., 2017). Yet, this optimistic belief in the possibility and desirability of exporting legal and market institutions ignores decades of literature on the problems associated with 'legal transplants' from the West to the rest (e.g. Pistor \& Berkowitz, 2003).

\section{Salvaging institutional voids? Gaps, swamps, and interfaces}

As institutional voids stretch conceptually and spread in usage, some authors have acknowledged the shortcomings of the term and have attempted to refine the concept. Some entrepreneurship scholars, for example, helpfully use more specific language such as 'formal institutional voids' to qualify their scope to legal and enforcement institutions (Puffer, McCarthy, \& Boisot, 2010; Sutter, Webb, Kistruck, \& Bailey, 2013). Alternatively, in a recent attempt to rectify the conceptual shortcomings of institutional voids, Olthaar et al. (2017) coin the also rather disparaging term 'institutional swamp' to capture the complexity and richness of institutional fabrics in non-Western countries. Meanwhile, scholars in Corporate Social Responsibility employ the term 'governance gaps' (Scherer \& Palazzo, 2011) to designate the outcomes of the nation-state's declining legal and democratic control 
over corporate activity. Although the notion does not privilege a priori any specific content of the desired governance arrangement, it is still based on the idea that something 'is not' but 'ought to be' there and dismisses the possibility that economic activities and exchange may be regulated in ways other than through a formalized regulatory order. Therefore, although 'governance gaps' and 'formal institutional voids' are a step in the right direction, even these approaches are still rather ethnocentric and ultimately lacking in conceptual precision.

To date, we find that the most promising refinement of the institutional void concept is Mair et al.'s (2012) reconceptualization of institutional void as interfaces between different institutional orders. Mair et al. (2012: 820) explictly reject the original, narrow view of institutional voids as spaces 'empty of specific institutions'. Instead, they acknowledge institutional plurality and see voids as 'the intermediate outcome of conflict and contradiction among' different institutional orders such as the 'local political, community, and religious spheres' (Mair et al., 2012: 820).

Yet, like much of the entrepreneurship literature using the institutional void concept, this approach still presents market participation as an end in itself and market-based economic orders as an inevitable - if not necessarily desirable - end-point. Acknowledging the value of alternative arrangements as 'intermediate outcomes' along this path, the authors retain an evolutionary ontology towards a superior, more ideal economic order, namely the 
market order. Local institutions, rather than constituting legitimate ways of organizing society and the economy, are explicitly considered as 'not ideal' (Mair et al. 2012: 843), but something 'market-builders' should acknowledge and use to promote Western-style markets with perhaps a bit of local flair.

Recasting institutional voids as institutional interfaces is an important shift from the original, 'absolutist' conception of institutional voids towards a relativist conception (i.e. alternative orders have value insofar as they can support the emergence of a market order). In this sense, the ethnocentrism of the concept is diluted. Nonetheless, it fails to question the implicit normative hierarchy of institutional orders - an evolutionist view implying that history has a definitive direction from the primitive, the archaic, the underdeveloped (nonmarkets) towards the sophisticated, the modern, the developed (markets). Clastres (1987) discerned in Western anthropologists a tendency to perceive other societies as the image of what we no longer are, and our societies as what other societies should strive to become. This biologist imagery - also reflected in labels such as "emerging" and "developing" economies - reinforces the view that the Western societies are the adult, the fully-fledged order, while 'developing' countries are at a less advanced stage progressing in that right direction.

Mair et al.'s (2012) objective is to understand how markets can be made more inclusive by empowering women to participate in the emerging market order in rural 
Bangladesh and thus obtain a fair share of the benefits of 'development'. The inclusion of women in markets where they exist can hardly be criticized. Yet what the notion of institutional voids surmises is that we agree that the emergence of a market order is a desirable goal for rural Bangladesh. But what if we do not? What if we have doubts whether integration in a market-based world economy is the only 'way forward' for all regions, countries, and communities in the world? While market mechanisms may allow communities to address non-financial issues (e.g. gender discrimination or poverty) through market solutions (Banerjee \& Jackson, 2016; Mair \& Marti, 2009), it does not follow that non-market solutions are inferior or less legitimate per se. It is at that level of disagreement that the institutional void concept - whether in its weak (relativist) or its strong (absolutist) formulation - becomes fundamentally problematic.

\section{A better future: decolonizing institutional voids and creating inclusive concepts}

Given the disquieting evolution of institutional voids and the insufficient remedies, how should we proceed? We advocate for management and organization scholars to engage in an epistemological rupture (Bachelard, 1938) to explicitly and fundamentally rethink the position of the Western scholar when studying other parts of the world. An epistemological rupture requires systematically questioning our deeply embedded assumptions and seeking 
to break free of these entrenched bonds. So what does an epistemological rupture look like in practice? We offer some initial steps forward:

Void institutional voids. Although efforts to introduce contextualization in management and organizational scholarship are important, this task is hardly possible through an umbrella term like institutional voids. Accordingly, tinkering with a fundamentally flawed concept that is rooted in a ethnocentric approach to management and organization studies will not solve the problem. As a starting point we thus propose dropping institutional voids from our academic lexicon. Further, we doubt that discovery of a 'better' concept will be possible or useful; an epistemological rupture means developing a new lexicon to describe non-Western contexts that emerges more organically from a rich understanding of local settings.

Embrace teleological diversity. We need to reckon with the ontological assumption - deeply embedded in much of management and organization studies - that formal market development is the most important societal goal. Indeed, we should question market development that facilitates economic inequality and reduces societal health (Pickett and Wilkinson, 2015) and happiness (Alesina, Di Tella, \& MacCulloch, 2004). Relatedly, we must recognize that the market facilitating Rule-of-Law (including the preference for publicly known, fixed and non-arbitrary rules) is a construct rooted in the Western 
Enlightenment tradition, while other parts of the world may rely on unwritten social norms to guide behaviours (Jacques, 2009). To a Western scholar, a moral order may appear as an institutional void to be rectified, while to an observer from a non-western country, it may plausibly appear as a sign of a healthy society based on a functioning moral order (Lau \& Young, 2013; Peerenboom, 2002).

Our research, as organization scholars, should consider and appreciate alternative societal goals. Embracing teleological diversity might further help to avoid the problematic elevation of Western economies to a gold standard while caricaturizing non-Western economies according to their supposed weaknesses. Indeed, new concepts can invert this formula: non-Western economies can have institutional strengths that Western economies lack, a fact that should be reflected in our academic lexicon. The new realities of the global economy require scholars in Western-dominated academia to rethink comparative analysis beyond facile benchmarking. Indeed, an epistemological rupture consists of abandoning the idea of a linear evolution of institutional orders or even a hierarchy among them.

Appreciate informal institutions. A singular focus on market-creating legal institutions obscures and denigrates the vibrant array of alternative institutions that nonetheless facilite exchange (Ledeneva, 2018). Indeed, we may well attribute the economic development of the United States to a work ethic derived from a religious institutional order 
(Weber, 1958) or to heavy state intervention (Mazzucato, 2015). Yet such influences are not captured from an institutional void perspective. There is much work to be done to uncover the prevalence, complexity, and power of informal institutions such as those embedded in family, religion, community, and culture. In this way, we also aim for researchers to recognize formal Western, market-oriented institutional arrangements as not an ideal endstate, but as one possible permutation of a broad array of institutional building blocks.

Conduct context-driven research. An epistemological rupture means considering that accumulated management and organization theory (including but not limited to institutional voids) may actually be hindering authentic understanding of non-Western contexts. Instead, we advocate building theory from the ground up with a close connection to the context. Although it is impossible for a researcher to enter a context as a blank slate (Suddaby, 2006), grounded theory requires that the fieldworker enter a context with the intention to 'make the familiar strange rather than the strange familiar' (van Maanen, 1995, p. 20). In other words, rather than traveling the world like an (academic) tourist who only 'sees what he came to see' - which in turn is determined by expectations, preconceptions and prejudices - we should become travelers 'who see what they [locals] see' (Chesterton, 2006[1936]: 305). Current research emphasizes contextualizing theory through stretching and retrofitting Western academic concepts; future research should develop concepts that more carefully 
capture the institutional fabric present in a given environment. In doing so, not only does an epistemological rupture in research culture allow us to truly understand other countries' institutional arrangements, it will also ultimately allow us to better understand our own. To paraphrase G.K. Chesterton once again, '[t]he whole object of travel is not to set foot on foreign land; it is at last to set foot on one's own country as a foreign land' (Chesterton, 2007[1909]:93).

Develop an inclusive research community. While perhaps not quite as overtly offensive as 'shithole country', 'institutional void' is still a stark and loaded term. Words matter. Using value-laden language not only poses an obstacle to building a collegial and vibrant intellectual community across peers from diverse cultural backgrounds, it also threatens the integrity of theoretical development itself. How can we truly understand the complexity and richness of phenomena in non-Western economies, let alone build sound theory to explain it, if our vocabulary is patronizing to those best suited to engage in this theorizing? We must bring in local scholars to allow indigenous theorization (Nkomo, 2017). As our profession seeks to explain increasingly diverse phenomena and context, we need to build our reflective capabilities, be inclusive in our approach, and conscientious of the power of the language we use. These principes are far from the final word, though hopefully, they are a start. 


\section{References}

Alesina, A., Di Tella, R., \& MacCulloch, R. (2004). Inequality and Happiness: Are Europeans and Americans different? Journal of Public Economics, 88, 2009-2042.

Allen, M. (2004). The Varieties of Capitalism Paradigm: Not enough Variety? SocioEconomic Review, 2, 87-108.

Anheier, H. K. (2014). Institutional Voids and the Role of Civil Society: the Case of Global Finance. Global Policy, 5, 23-35.

Bachelard, G. (1938). The Formation of the Scientific Mind. Paris, France: Gallimard.

Bae, K., Kang, J., \& Kim, J. (2002). Tunneling or Value Added? Evidence from Mergers by Korean Business Groups. The Journal of Finance, 57, 2695-2740.

Baker, T., \& Nelson, R. E. (2005). Creating Something from Nothing: Resource Construction through Entrepreneurial Bricolage. Administrative Science Quarterly, 50, $329-366$.

Banerjee, S. B. (2003). Who Sustains Whose Development? Sustainable Development and the Reinvention of Nature. Organization Studies, 24, 143-180.

Banerjee, S. B., \& Jackson, L. (2016). Microfinance and the Business of Poverty Reduction: Critical Perspectives from Rural Bangladesh. Human Relations, 1-29.

Beveridge, R. (2012). Consultants, Depoliticization and Arena-shifting in the Policy 
Process: Privatizing Water in Berlin. Policy Sciences, 45, 47-68.

Carney, M., Gedajlovic, E. R., Heugens, P. P. M. A. R., Van Essen, M., \& Van Oosterhout, J. (2011). Business Group Affiliation, Performance, Context, and Strategy: A Metaanalysis. Academy of Management Journal, 54, 437-460.

Castellacci, F. (2015). Institutional Voids or Organizational Resilience? Business Groups, Innovation, and Market Development in Latin America. World Development, 70, 4358.

Chang, S. J., \& Hong, J. (2000). Economic Performance of Group-Affiliated Companies in Korea: Intragroup Resource Sharing and Internal Business Transactions. Academy of Management Journal, 43, 429-448.

Chittoor, R., Kale, P., \& Puranam, P. (2015). Business Groups in Developing Capital Markets: Towards a Complementarity Perspective. Strategic Management Journal, 36, $1277-1296$.

Clastres, P. (1987). Society Against the State: Essays in Political Anthropology. New York, NY: Zone Books.

CMS. (2017). CMS-India Corruption Study 2017. New Delhi, India.

Cumming, D., Filatotchev, I., Knill, A., Reeb, D. M., \& Senbet, L. (2017). Law, Finance, and the International Mobility of Corporate Governance. Journal of International 
Business Studies, 48, 1-25.

Dar, S. (2017). De-Colonizing the Boundary-Object. Organization Studies, 39, 565-584.

Davies, I. A., \& Torrents, A. (2017). Overcoming Institutional Voids in Subsistence Marketplaces. Journal of Macromarketing, 37, 255-267.

Deakin, S., \& Sarkar, P. (2008). Assessing the Long-run Economic Impact of Labour Law Systems: A Theoretical Reappraisal and Analysis of New Time Series Data. Industrial Relations Journal, 39, 453-487.

Estrin, S., \& Prevezer, M. (2011). The Role of Informal Institutions in Corporate Governance: Brazil, Russia, India, and China compared. Asia Pacific Journal of Management, 28, 41-67.

Fisman, R., \& Khanna, T. (2004). Facilitating Development: The Role of Business Groups. World Development, 32, 609-628.

Gedajlovic, E. R., Carney, M., Chrisman, J. J., \& Kellermanns, F. W. (2012). The Adolescence of Family Firm Research: Taking Stock and Planning for the Future. Journal of Management, 38, 1010-37.

Getachew, Y. S., \& Beamish, P. W. (2017). Foreign Subsidiary Exit from Africa: The Effects of Investment Purpose Diversity and Orientation. Global Strategy Journal, 7, $58-82$. 
Ghoul, S. El, Guedhami, O., \& Kim, Y. (2017). Country-level Institutions, Firm Value, and the Role of Corporate Social Responsibility Initiatives. Journal of International Business Studies, 48, 360-385.

Gilley, B. (2018). The Case for Colonialism. Academic Questions, 31, 167-185.

Graeber, D. (2014). Debt: The first 5,000 years. New York, NY: Melville House.

Hall, P. A., \& Soskice, D. (2001). Varieties of Capitalism: The Institutional Foundations of Comparative Advantage. Oxford, UK: Oxford University Press.

Hanekom, D., \& Luiz, J. M. (2017). The Impact of Multinational Enterprises on Public Governance Institutions in Areas of Limited Statehood. Management Decision, 55, $1736-1748$.

Hirsch, P. M., \& Levin, D. Z. (1999). Umbrella Advocates Versus Validity Police: A LifeCycle Model. Organization Science, 10, 199-212.

Hoskisson, R. E., Johnson, R. A., Tihanyi, L., \& White, R. E. (2005). Diversified Business Groups and Corporate Refocusing in Emerging Economies. Journal of Management, $31,941-965$.

IMD. (2005). The World Competitiveness Scoreboard 2005. Lausanne, Switzerland.

Jacques, M. (2009). When China Rules the World. London: Penguin Books.

Khanna, T., \& Palepu, K. (1997). Why Focused Strategies May Be Wrong for Emerging 
Markets. Harvard Business Review, 75, 41-48.

Khanna, T., \& Palepu, K. (2000a). Is Group Affiliation Profitable in Emerging Markets? An Analysis of Diversified Indian Business Groups. The Journal of Finance, 55, 867891.

Khanna, T., \& Palepu, K. (2000b). The Future of Business Groups in Emerging Markets: Long-Run Evidence From Chile. Academy of Management Journal, 43, 268-285.

Khanna, T., \& Palepu, K. G. (2010). Winning in Emerging Markets: A Road Map for Strategy and Execution. Cambridge, MA: Harvard Business Press.

Khanna, T., \& Rivkin, J. W. (2001). Estimating the Performance Effects of Business Groups in Emerging Markets. Strategic Management Journal, 74, 45-74.

Kipping, M., \& Engwall, L. (2002). Management Consulting: Emergence and Dynamics of a Knowledge Industry. Oxford, UK: Oxford University Press.

La Porta, R., Lopez de Silanes, F., Shleifer, A., \& Vishny, R. W. (1998). Law and Finance. Journal of Political Economy, 106, 1113-55.

Ledeneva, A. V. (2018). The Global Encyclopaedia of Informality, Volume 2. London, UK: UCL Press.

Leff, N. H. (1978). Industrial Organization and Entrepreneurship in the Developing Countries: The Economic Groups. Economic Development and Cultural Change, 26, 
$661-675$.

Luo, X. R., \& Chung, C.-N. (2013). Filling or Abusing the Institutional Void? Ownership and Management Control of Public Family Businesses in an Emerging Market. Organization Science, 24, 591-613.

Mair, J., \& Marti, I. (2009). Entrepreneurship in and around Institutional Voids: A case study from Bangladesh. Journal of Business Venturing, 24, 419-435.

Mair, J., Marti, I., \& Ventresca, M. J. (2012). Building Inclusive Markets in Rural Bangladesh: How Intermediaries Work Institutional Voids. Academy of Management Journal, 55, 819-850.

Manikandan, K. S., \& Ramachandran, J. (2015). Beyond Institutional Voids: Business Groups, Incomplete Markets and Organizational Form. Strategic Management Journal, 36, 598-617.

Mazzucato, M. (2015). The Entrepreneurial State: Debunking Public vs. Private Sector Myths. London, UK: Anthem Press.

Mishra, P. (2017). Age of Anger: A History of the Present. New York, NY: Farrar, Straus, and Giroux.

Nkomo, S. M. (2017). Time to Look in the Mirror: Producing Management Theory and Knowledge for Africa. Africa Journal of Management, 3, 7-16. 
North, D. C. (1990). A Transaction Cost Theory of Politics. Journal of Theoretical Politics, $2,355-367$.

Olthaar, M., Dolfshma, W., Luts, C., \& Noseleit, F. (2017). Markets and Institutional Swamps: Tensions confronting Entrepreneurs in Developing Countries. Journal of Institutional Economics, 13, 243-269.

Ozkazanc-Pan, B. (2008). International Management Research Meets The Rest of the World. Academy of Management Review, 33, 964-974.

Peerenboom, R. (2002). China's Long March toward Rule of Law. Cambridge, UK: Cambridge University Press.

Pinkham, B. C., \& Peng, M. W. (2017). Overcoming Institutional Voids via Arbitration. Journal of International Business Studies, 48, 344-359.

Pistor, K., \& Berkowitz, D. (2003). Of Legal Transplants, Legal Irritants, and Economic Development. In P. K. Cornelius \& B. Kogut (Eds.), Corporate Governance and Capital Flows in a Global Economy (pp. 347-368). Oxford, UK: Oxford University Press.

Puffer, S. M., McCarthy, D. J., \& Boisot, M. (2010). Entrepreneurship in Russia and China: The Impact of Formal Institutional Voids. Entrepreneurship Theory and Practice, 34, $441-467$. 
Rothbard, M. N. (1981). The Myth of Neutral Taxation. Cato Journal, 1, 519-564.

Santangelo, G. D., \& Meyer, K. E. (2011). Extending the Internationalization Process Model: Increases and Decreases of MNE Commitment in Emerging Economies. Journal of International Business Studies, 42, 894-909.

Sartori, G. (1970). Concept Misformation in Comparative Politics. The American Political Science Review, 64, 1033-1053.

Scherer, A. G., \& Palazzo, G. (2011). The New Political Role of Business in a Globalized World: A Review of a New Perspective on CSR and its Implications for the Firm, Governance, and Democracy. Journal of Management Studies, 48, 899-931.

Scott, W. R. (2014). Institutions and Organizations: Ideas, Interests, and Identities. Thousand Oaks, CA: SAGE Publications.

Suddaby, R. (2006). From the Editors: What Grounded Theory is not. Academy of Management Journal, 49, 633-642.

Sutter, C. J., Webb, J. W., Kistruck, G. M., \& Bailey, A. V. G. (2013). Entrepreneurs' Responses to Semi-formal Illegitimate Institutional Arrangements. Journal of Business Venturing, 28, 743-758.

van Maanen, J. (1995). An End to Innocence: The Ethnography of Ethnography. In J. van Maanen (Ed.), Representation in Ethnography (pp. 1-35). Thousand Oaks, CA: SAGE 
Publications.

Weber, M. (1958). The Protestant Ethic and the Spirit of Capitalism (Translated by T. Parsons). Mineola, NY: Dover Publications.

Williamson, O. E. (1981). The Economics of Organization: The Transaction Cost Approach. American Journal of Sociology, 87, 548-577.

Yiu, D. W., Lu, Y., Bruton, G. D., \& Hoskisson, R. E. (2007). Business groups: An integrated model to focus future research. Journal of Management Studies, 44, 15511579. 


\section{TABLES AND FIGURES}

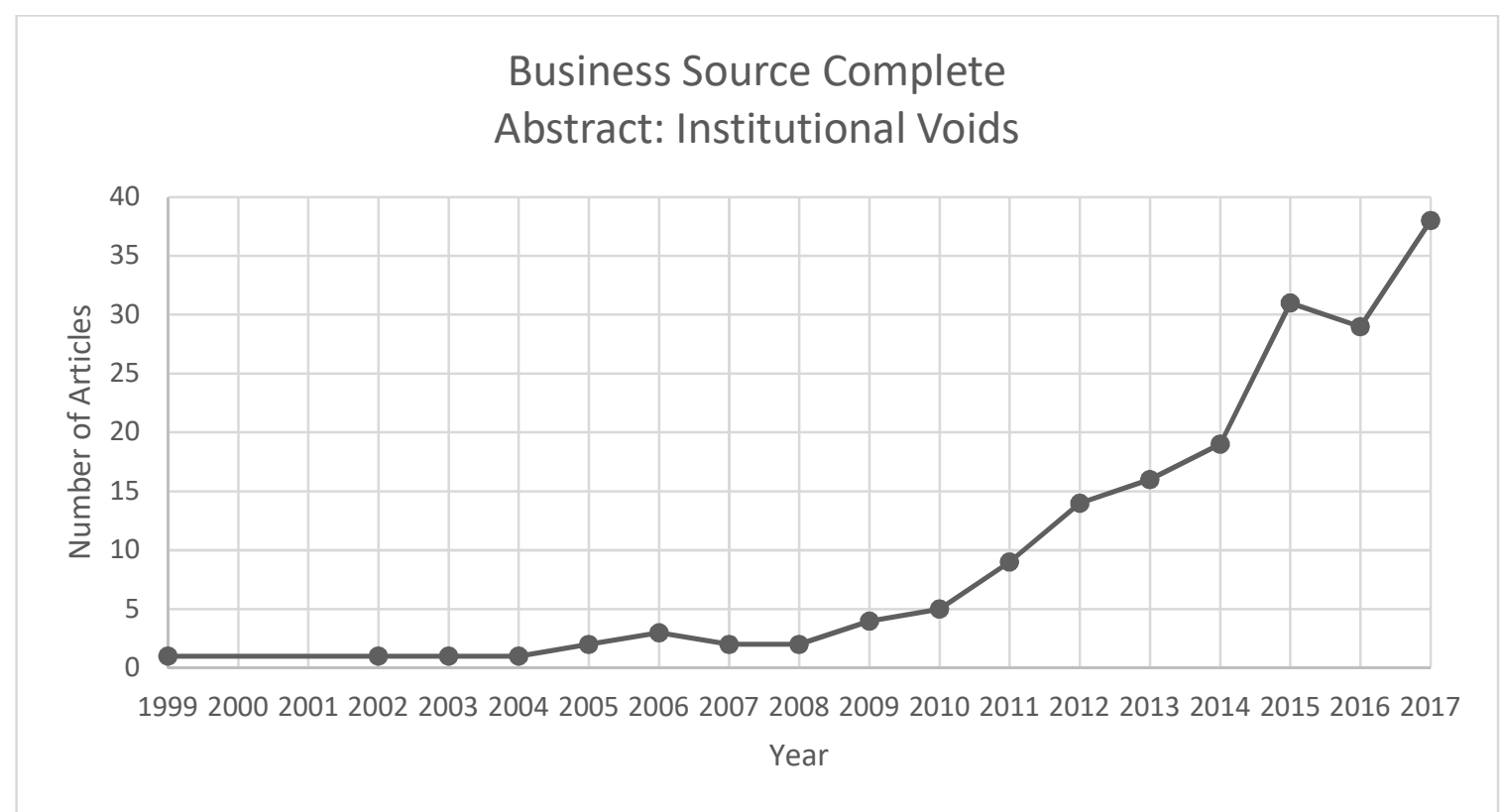

Figure 1. Growth in the use of the term institutional voids 


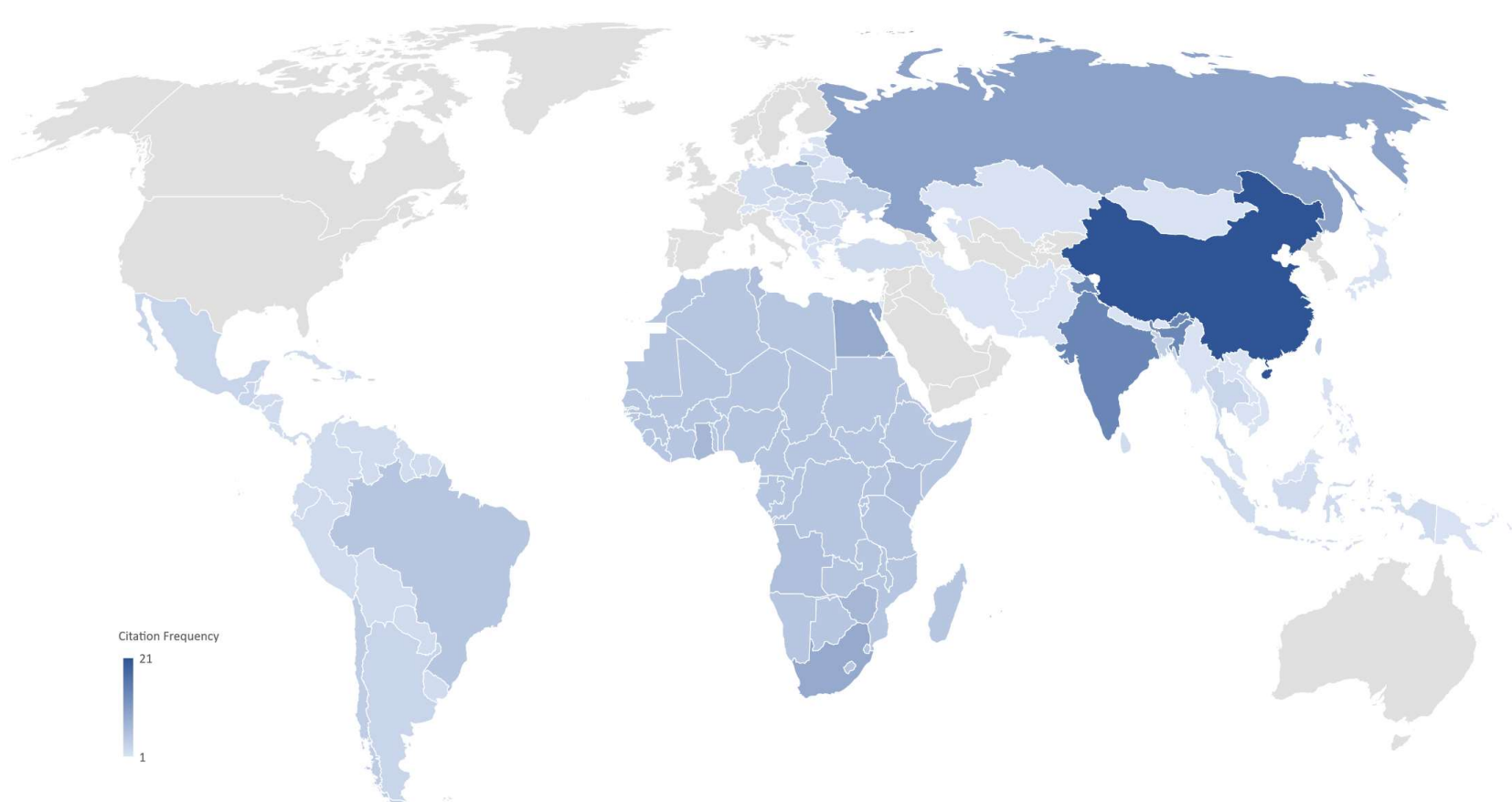

Figure 2. Countries/regions cited as institutional voids 